* Mestrando em Direito da Empresa e Atividades Econômicas pela Universidade do Estado do Rio de Janeiro (UERJ). Graduado em Direito pela Pontifícia Universidade Católica do Rio de Janeiro (PUC-Rio). Advogado. E-mail: higorbiana@gmail. com.

** Doutor em Ciências pela Escola Nacional de Saúde Pública Sérgio Arouca (ENSP) da Fundação Oswaldo Cruz (FIOCRUZ). Professor Adjunto de Direito Comercial da Faculdade de Direito da Universidade do Estado do Rio de Janeiro (UERJ). Professor do Programa de Pós-Graduação em Direito da mesma instituição. E-mail: 1santanna44@ gmail.com.

\section{Apontamentos sobre a Arbitragem \\ no Contrato de Franquia}

Notes on Arbitration IN the Franchise

ARRANGEMENT

\section{Higor da Silva Biana* Leonardo da Silva Sant'Anna**}

Como citar: BIANA, Higor da Silva; SANT'ANNA, Leonardo da Silva.Apontamentos sobre a arbitragem no contrato de franquia. Scientia Iuris, Londrina, v. 21, n. 1, p.125-154, mar. 2017. DOI: $10.5433 / 2178-8189.2017 \mathrm{v} 21$ n1p125. ISSN: 2178-8189.

Resumo: A arbitragem, hodiernamente apontada como alternativa de solução de conflitos mais célere e especializada que a jurisdição estatal, apresenta-se como meio viável para a heterocomposição de litígios emergidos das relações de franquia. O presente trabalho propõe-se a uma análise de questões controversas atinentes à inserção da cláusula compromissória nos contratos de franquia, quais sejam: se o franqueador deve informar sobre os procedimentos arbitrais em que esteja envolvido do mesmo modo que deve fazê-lo com relação às pendências judiciais; a validade da cláusula compromissória com relação ao franqueado hipossuficiente; e os requisitos para a inserção da cláusula compromissória no 
contrato de franquia, inclusive quando este for caracterizado como sendo de adesão.

Palavras-chave: Contrato de franquia. Franchising. Arbitragem. Cláusula compromissória. Soluções alternativas de resolução de conflitos.

Abstract: Arbitration, usually indicated as a faster and more specialized alternative for dispute resolution than state jurisdiction, is a viable option for emerging conflicts from franchise relations. Furthermore, this paper proposes an analysis of controversial issues related to the inclusion of the arbitration clause in franchise contracts. These issues can range from whether the franchisor should inform the arbitration proceedings, in which he is involved, as well as with pending judicial matters; to the validity of the arbitration clause with respect to the economically disadvantaged franchisee; and the requirements applicable to the insertion of the arbitration clause in the franchise agreement, including those characterized as adhesion agreements.

Keywords: Franchise agreement. Franchising. Arbitration. Arbitration clause. Alternative dispute resolution. 


\section{INTRODUÇÃO}

A relação de franquia é, em apertada síntese, aquela por meio da qual o franqueador licencia sua marca e, cumulativamente, presta serviços para que o franqueado exerça a empresa. Comumente, estabelecem-se outras obrigações, inclusive a de que os produtos a serem comercializados ou utilizados como insumo pelo franqueado sejam fornecidos pelo franqueador.

Os contratos de franquia são tidos como complexos, pois hodiernamente disciplinam, em uma mesma senda, a propriedade intelectual das partes, prestação de serviços, negócios de compra e venda, etc. Por esta razão, não raras vezes franqueador e franqueado divergem acerca dos seus direitos e obrigações.

Nesta medida, como a relação de franquia diz respeito a atividades econômicas desenvolvidas mediante o emprego de recursos patrimoniais tanto do franqueado como do franqueador - ordinariamente considerados direitos patrimoniais disponíveis -, a arbitragem apresentase como uma viável solução alternativa de solução de conflitos.

A propósito, em que pese à essencialidade do exercício jurisdicional pelo Estado, o emprego de alternativas não estatais para a resolução de conflitos vem assumindo relevo diante da famigerada morosidade na obtenção de decisões definitivas pelo poder judiciário.

Lembre-se que, no que se refere às relações empresariais - nas quais se insere a franquia - a demora na solução de determinado conflito por meio de heterocomposição pode até mesmo levar à bancarrota o empreendedor titular de direitos inobservados - o que não representaria uma excepcionalidade na realidade brasileira.

Com efeito, a celeridade e a especialidade são os principais 
aspectos que fazem da arbitragem o mais relevante meio alternativo de solução de conflitos. Como ressaltam Cachapuz e Condado (2008, p. 97), o advento do atual arcabouço legal da arbitragem - a Lei n. 9.307, de 23 de setembro de 1996 - "“...] significa uma verdadeira revolução na cultura jurídica brasileira, à medida que coloca lado a lado a jurisdição estatal com a privada, à escolha do jurisdicionado [...]”.

De toda sorte, tendo em vista que, de um lado, a adoção da arbitragem significa às partes abrirem mão da sua prerrogativa de acesso à jurisdição estatal, é imprescindível que as normas legais sejam apropriadamente aplicadas. Desse modo, é necessário compreender o alcance e sentido das normas e institutos incidentes especificamente à adoção da arbitragem na relação de franquia.

Neste trabalho, será primeiramente colocada a questão se, previamente à celebração do contrato de franquia, o franqueador deve informar dos procedimentos arbitrais do mesmo modo que lhe cumpre fazer com relação às pendências judiciais. Então, se adentrará na problemática da validade da cláusula arbitral perante um franqueado hipossuficiente, após o que serão elencados os requisitos para a formalização da referida convenção arbitral no âmbito dos contratos de franquia, mormente aqueles que venham a ser caracterizados como sendo de adesão.

Em vista da obrigação imposta ao franqueador pelo artigo $3^{\circ}$, inciso III, da Lei n. 8.955, de 15 de dezembro de 1994 (Lei de Franquia), de acordo com o qual ele deve indicar ao franqueado todas as pendências judiciais sobre o sistema da franquia ${ }^{1}$ em que esteja envolvido ${ }^{2}$, é de suma importância investigar se está obrigado a informar o franqueado sobre os

1 Ou que possam diretamente vir a impossibilitar o funcionamento da franquia.

2 Diretamente ou por meio de sociedades empresárias, as empresas controladoras e titulares de marcas, patentes e direitos autorais relativos à operação, e seus subfranqueadores. 
litígios envolvendo o mesmo objeto, contudo, submetidos à arbitragem.

Deve-se também levar em conta o franqueado que, em posição econômica desfavorecida comparativamente ao franqueador, estabelece uma relação de franquia na qual acorda que eventual resolução de conflito se dará por meio da arbitragem. Para tanto, será analisada a hipótese em que esta condição do franqueado seja conhecida no ato da celebração da convenção arbitral. E também caso verificada a hipossuficiência no momento da instauração do litígio.

No que se refere aos requisitos aplicáveis à inserção da cláusula compromissória no contrato de franquia, será apontado que não raras vezes o franqueador impõe o mesmo modelo de contrato para todos seus franqueados, de modo que deve ser adotada a tutela da autonomia da vontade nos contratos de adesão.

Para a análise das aludidas questões envolvendo o instituto da arbitragem e a relação empresarial de franquia, o presente trabalho lança mão da vertente metodológica jurídico-teórica, alicerçando-se nas normas aplicáveis e doutrinas correspondentes, sendo metodologicamente organizado de modo a, inicialmente, apresentar as principais características do contrato de franquia e da arbitragem, após o que serão investigadas as referidas problemáticas centrais relativas à inserção de cláusulas compromissórias ${ }^{3}$ nos referidos contratos.

\section{O SISTEMA DE FRANQUIA}

Os contornos ora presentes na franquia empresarial - também denominada franchising - remontam à segunda metade do século XIX,

3 Esta constitui a convenção por meio da qual as partes de um contrato comprometem-se a submeter os litígios dele derivados à arbitragem.

SCIENTIA IURIS, Londrina, v.21, n.1, p.125-154, Mar.2017 DOI: 110.5433/2178-8189.2017v21n1p125 
tendo como gênese o modelo de negócio adotado por diversas corporações estadunidenses que, com o propósito de difundir seus produtos, passaram a franquear o uso de suas marcas, técnicas e publicidade (BRAGA, 2015, p. 168-169).

A franquia é espécie do gênero contrato de cooperação ou colaboração, assim entendido aquele por meio do qual "[...] os empresários articulam suas iniciativas e esforços com vistas à criação ou consolidação de mercados consumidores para certos produtos" (COELHO, 2016, p. 103-104). Afinal, “[...] o traço essencial dessa categoria de contratos mercantis é exatamente a articulação entre as empresas das partes contratantes" (COELHO, 2016, p. 103-104).

A propósito, como bem anota Forgioni (2012, p. 135), a colaboração entre as sociedades empresárias tem sido uma característica cada vez presente no exercício das atividades econômicas, o que "[...] não se dá apenas por meio dos contratos de sociedade - forma típica de associação entre agentes econômicos - e, por óbvio, também não se concretiza por meros contratos de intercâmbio".

O contrato de franquia possui natureza complexa, uma vez que não constituindo uma relação de sociedade, engloba, sob a disciplina de um mesmo vínculo, múltiplas relações, que podem dizer respeito, sem limitação, ao licenciamento para uso de marca, transferência de tecnologia, prestação de serviços e/ou fornecimento de produtos.

Mencione-se que a Lei de Franquia define a franchising, em seu artigo $2^{\circ}$, como o sistema pelo qual um franqueador cede ao franqueado o direito de uso de marca ou patente, associado ao direito de distribuição exclusiva ou semiexclusiva de produtos ou serviços e, eventualmente, também ao direito de uso de tecnologia de implantação e administração de negócio ou sistema operacional desenvolvidos ou 
detidos pelo franqueador, mediante remuneração direta ou indireta, sem que, no entanto, fique caracterizado vínculo empregatício.

Entretanto, em que pese tal definição ser estabelecida no próprio diploma legal da franquia, parte da doutrina especializada a crítica sob o argumento de que seria indispensável à caracterização da franquia que o franqueador fornecesse ao franqueado direito de uso de marca.

Com base neste argumento, Braga $(2015,173-174)$ propõe o afastamento da interpretação literal do acima mencionado dispositivo legal e propõe uma definição para a franquia empresarial, que seria:

[...] o contrato pelo qual o franqueador, de um lado, concede ao franqueado, de outro, a licença de uso de uma marca associada à prestação de serviços de assessoria técnica para a implantação e desenvolvimento de um negócio de comercialização ou industrialização de produtos ou prestação de serviços pelo franqueado que, por sua vez, compromete-se a fazer tal comercialização de acordo com os padrões de comercialização definidos pelo franqueador.

Com as devidas vênias, a Lei de Franquia é clara no sentido de que a outorga do direito de uso de marca, ao invés de um requisito da franquia, é uma alternativa ao fornecimento do direito de uso de patente. E nada na legislação pátria ou na lógica da relação de franquia converge no sentido de que a referida outorga seria indispensável.

Pelo contrário, estabelecer tal necessidade poderia até mesmo engessar as possibilidades dos contornos desse contrato complexo. A propósito, tal como ocorre ao redor do mundo, também no Brasil o contrato de franquia não tem seu conteúdo balizado pela legislação. 
Esta geralmente limita-se a disciplinar certos aspectos da relação por ele estabelecida, como a transparência entre os contratantes, proteção ao consumidor e defesa da concorrência (BRAGA, 2015, p. 168-169).

Assim, mesmo sendo objeto de diploma legal brasileiro específico, o contrato de franquia é atípico. Sem embargo, aponta que comumente são estabelecidas certas obrigações aos franqueados e franqueadores que se repetem nas diversas espécies de franquia, como ressalta Coelho (2014, p. 493-494):

[...] costuma-se atribuir aos franqueados o seguinte conjunto de obrigações: a) o pagamento de uma taxa de adesão e de um percentual do seu faturamento; b) o pagamento pelos serviços de organização empresarial fornecidos pelo franqueador; c) a obrigação de oferecer aos consumidores apenas os produtos ou serviços da marca do franqueador, ou por ele fabricados, aprovados ou simplesmente indicados; d) observar, estritamente, as instruções e o preço de venda ao consumidor estabelecidos pelo franqueador. Por seu turno, o franqueador tem as seguintes obrigações: a) permitir ao franqueado o uso de sua marca; b) prestar os serviços de organização empresarial.

Nenhuma das mencionadas obrigações é estabelecida em razão de solenidade legal, ficando claro que a grande maior parte das cláusulas acordadas pelas partes do contrato de franquia são resultantes de livre pactuação.

Portanto, viabilizando ampla liberdade negocial entre franqueado e franqueador, a Lei de Franquia ocupa-se mais da questão informacional que obrigacional. Neste sentido, seu artigo $3^{\circ}$ estabelece 
que sempre que o franqueador tiver interesse na implantação de sistema de franquia empresarial, deverá fornecer ao potencial franqueado uma circular de oferta de franquia, por escrito e em linguagem clara e acessível, contendo, obrigatoriamente, uma série de informações atinentes ao negócio proposto.

Conforme mencionado na Exposição de Motivos do Projeto da Lei de Franquia, a aludida circular de oferta:

[...] tem por finalidade levar ao potencial franqueado as informações mais importantes a respeito do franqueador e do negócio no qual pretende engajarse [...]. Constitui-se, assim, em instrumento imprescindível ao potencial franqueado, pois reúne em um só documento as informações mais relevantes a respeito do negócio franqueado (BRASIL, 1991, p. 1).

Frise-se: a circular de oferta não constitui um contrato de franquia, mas tão somente uma proposta do franqueador. Após seu envio, subsistirá a possibilidade de discussão de cada um dos termos do contrato de franquia a ser eventualmente celebrado.

Para viabilizar a análise das informações disponibilizadas na circular de oferta previamente à celebração do contrato, este instrumento deve ser disponibilizado ao potencial franqueado com antecedência mínima de dez dias (artigo $4^{\circ}$ da Lei de Franquia).

Vale ressaltar que caso o franqueador não observe o aludido prazo de dez dias, ou ainda, veicule informações falsas na circular de oferta, poderá o franqueado pleitear a anulabilidade do contrato de franquia. Ademais, fará jus à devolução de todas as quantias que tiver pagado ao franqueador ou a terceiros por ele indicados, a título de taxa 
de filiação e royalties, além das indenizações pelas perdas e danos que incorrer.

No que tange às solenidades aplicáveis ao contrato de franquia, a legislação específica estabelece tão somente que este deverá ser firmado por duas testemunhas, dispensando, por outro turno, seu registro perante cartório ou órgão público (artigo $6^{\circ}$ da Lei de Franquia).

\section{AARBITRAGEM COMO MEIO DE SOLUÇÃO DE CONFLITOS}

Tal qual qualquer outra relação, a de franquia também é sujeita a conflitos. Por mais que o direito tenha por mote regular a cooperação e a atribuição de bens, isto não é suficiente para garantir a eliminação ou redução dos conflitos que possam emergir das pretensões individuais ou coletivas.

Assim, a função pacificadora do Estado, ou seja, de dirimir litígios, é de tal modo relevante que, como anotam Cintra, Grinover e Dinamarco (2009, p. 31), conduz "[...] à afirmação da quase absoluta exclusividade estatal no exercício dela". Este papel pacificador é praticado pelo Estado mediante o exercício jurisdicional, que se revela por meio das decisões proferidas pelo poder judiciário.

Como aclaram Massali e Cachapuz (2011, p. 168), a resolução de conflitos em que "[...] um terceiro, alheio ao conflito, profere decisão que vincula as partes ao seu cumprimento [...]" é denominada heterocomposição. Esta pode ser implementada tanto por meio da jurisdição estatal como da arbitragem, que é quando os sujeitos envolvidos no conflito convencionam que terceiros decidirão sobre o deslinde da lide.

Afora a arbitragem, há outras formas de eliminação de conflitos 
que são implementadas sem participação direta do Estado. É o caso da autotutela ${ }^{4}$ e da autocomposição, que igualmente dizem respeito a iniciativas das próprias partes envolvidas no litígio.

Como ensinam Cintra, Grinover e Dinamarco (2009, p. 26-27), na autotutela, um sujeito imporia ao outro o sacrifício do seu interesse, lançando mão, para tanto, dos instrumentos de que dispusesse. Releva salientar que a evolução do direito cambou em direção à proibição deste meio de resolução de conflitos, e não por outra razão, o Código Penal o tipifica como crime, seja praticada pelos indivíduos ${ }^{5}$ ou pelo próprio Estado ${ }^{6}$.

$\mathrm{Na}$ esteira destas mesmas lições, os doutrinadores esclarecem que na autocomposição o conflito é resolvido mediante renúncia total ou parcial, por um ou ambos os sujeitos, dos seus interesses.

Contudo, apesar de amplamente estimulada no atual contexto em que se verifica vertiginoso aumento no número de processos judiciais, a autocomposição tem como empecilho prático a necessidade de aceitação, por uma ou ambas as partes litigantes, em abrir mão do todo ou parcela do interesse objeto da pretensão.

Na medida em que a autotutela é proibida por nosso ordenamento jurídico e a autocomposição não se apresenta tão efetiva diante dos casos concretos, a heterocomposição permanece despontando historicamente

4 Também denominada autodefesa.

5 Exercício arbitrário das próprias razões: Art. 345 - Fazer justiça pelas próprias mãos, para satisfazer pretensão, embora legítima, salvo quando a lei o permite: Pena - detenção, de quinze dias a um mês, ou multa, além da pena correspondente à violência. Parágrafo único - Se não há emprego de violência, somente se procede mediante queixa.

6 Exercício arbitrário ou abuso de poder: Art. 350 - Ordenar ou executar medida privativa de liberdade individual, sem as formalidades legais ou com abuso de poder: Pena - detenção, de um mês a um ano Parágrafo único - Na mesma pena incorre o funcionário que: I - ilegalmente recebe e recolhe alguém a prisão, ou a estabelecimento destinado a execução de pena privativa de liberdade ou de medida de segurança; II - prolonga a execução de pena ou de medida de segurança, deixando de expedir em tempo oportuno ou de executar imediatamente a ordem de liberdade; III - submete pessoa que está sob sua guarda ou custódia a vexame ou a constrangimento não autorizado em lei; IV - efetua, com abuso de poder, qualquer diligência. 
como a forma mais usual de resolução de conflitos. Mas quando exercida mediante a jurisdição estatal, esta forma tem na morosidade do judiciário seu maior entrave.

Esta externalidade negativa é usualmente justificada pelas as formalidades impostas com vistas a assegurar garantias das partes. Por esta razão Cintra, Grinover e Dinamarco (2009, p. 32-33) ensinam que mesmo sendo a desformalização um dos principais fatores a estimular a solução dos conflitos por meios não jurisdicionais, não pode se dar em detrimento das garantias processuais.

É em virtude destas garantias, a arbitragem é balizada por solenidades que acertadamente impedem que os procedimentos arbitrais passem ao largo de requisitos legais e constitucionais.

A propósito, haja vista a abordagem a que se propõe, o presente trabalho não abarcará os institutos aplicáveis de maneira restrita à arbitragem, sem conexão com a relação de franquia.

Nesta senda, este estudo se limitará à análise da eventual obrigação do franqueador de informar aos franqueados sobre os procedimentos arbitrais relacionados à franquia em que esteja envolvido, dos requisitos aplicáveis à celebração da cláusula compromissória nos contratos de franquia e à validade do pacto arbitral para o franqueado hipossuficiente.

De todo modo, cabe apontar que os requisitos impostos à arbitragem por força de disposições constitucionais e legais estão longe de neutralizar os benefícios que ela confere; não sem razão, ela consolidouse como um meio cada vez mais adotado em substituição à jurisdição estatal, o que se reflete no crescimento do número de câmaras arbitrais observado nos últimos anos.

Com efeito, além de mais propensa ao atendimento dos anseios 
de quem teve um bem jurídico violado - na medida em que não pressupõe que abra mão de seus interesses, como seria o caso da autocomposição - a arbitragem confere vantagens que, como indicado por Massali e Cachapuz (2011, p. 178), vão além da celeridade:

a) Celeridade: o procedimento adotado pelas partes é bem mais célere do que aquele trazido pelo Judiciário. Os próprios interessados podem fixar o prazo em que deve ser proferida a decisão, e não o fazendo, será este de seis meses.

b) Informalidade: o procedimento aplicável à arbitragem, até porque pode ser definido pelas partes, é bem mais simples e informal do que aquele visualizado no processo judicial. A única observação é que essa escolha deve respeitar os princípios constitucionais de observância obrigatória, tais quais o contraditório, a ampla defesa, etc.

c) Irrecorribilidade das decisões: as decisões dos árbitros, em regra, são irrecorríveis, o que torna mais ágil o procedimento e faz alcançar, com maior celeridade, o resultado final do processo arbitral.

Ademais, outra enorme vantagem é a confidencialidade: diferentemente dos processos judiciais, os procedimentos arbitrais e as decisões proferidas não possuem caráter público ${ }^{7}$. Além disso, outro atrativo é a possibilidade de as próprias partes nomearem julgadores especializados na matéria discutida no litígio.

\section{A CLÁUSULA COMPROMISSÓRIA NOS CONTRATOS DE FRANQUIA}

7 A ausência de publicidade nas decisões pode, por outro lado, representar uma desvantagem, uma vez que não viabiliza o conhecimento dos entendimentos consolidados por determinada câmara arbitral. 
Não há óbices à adoção da cláusula compromissória no âmbito das relações de franquia ${ }^{8}$. Pelo contrário, a arbitragem pode trazer diversos benefícios às partes do contrato de franquia em caso de eventual conflito.

Mas para que seu estabelecimento no âmbito da relação de franquia seja verdadeiramente vantajoso, lícito e conforme os fins a que se destina, é primordial não somente uma observância literal dos requisitos legais aplicáveis, mas também que estes sejam interpretados à luz do negócio jurídico sobre o qual incidirá. Em razão deste fato, serão analisadas a seguir algumas das principais controvérsias que circundam a inserção da cláusula compromissória no contrato de franquia.

As problemáticas que se colocam não dizem respeito somente aos requisitos legais para a celebração desta convenção arbitral - o que será feito ao final deste capítulo, inclusive no que se refere aos contratos de franquia caracterizados como de adesão. Serão também investigadas as questões da eventual obrigação do franqueador de apresentar previamente informações acerca dos procedimentos arbitrais, conforme deve fazer com relação às pendências judiciais, e da validade da cláusula compromissória perante $\mathrm{p}$ franqueado hipossuficiente.

\subsection{A abrangência da obrigação de informar sobre as pendências}

8 Verifica-se que uma das maiores divergências doutrinárias ora em voga relacionadas à adoção da arbitragem diz respeito à utilização deste meio de resolução de conflitos nas relações consumeristas. De todo modo, não sendo a franquia caracterizada como uma relação de consumo, seria inaplicável o dispositivo em torno do qual circundam as mencionadas discussões: trata-se do artigo 51, inciso VII da Lei n. 8.078, de 11 de setembro de 1990 (Código de Defesa do Consumidor), nos termos do qual seria nula a cláusula contratual relativa ao fornecimento de produtos e serviços que determinasse a adoção compulsória da arbitragem. Com efeito, a doutrina debruça-se justamente sobre o que caracterizaria essa compulsoriedade. Contudo, além de a relação empresarial de franquia contar com legislação própria, o franqueado não é o destinatário final dos produtos ou serviços objeto do contrato de franquia, razão pela qual não pode ser caracterizado como consumidor nos termos do artigo $2^{\circ}$ do Código de Defesa do Consumidor. 


\section{judiciais do franqueador às arbitragens}

A Lei de Franquia estabelece que, por meio da já mencionada circular de oferta, o proponente franqueador forneça ao potencial franqueado uma série de informações que relevaria a este saber previamente à celebração de uma relação de franquia. Neste sentido, o inciso III do artigo $3^{\circ}$ da Lei de Franquia estabelece que deverá constar neste documento a indicação precisa de todas as pendências judiciais ${ }^{9}$ questionando o sistema da franquia ou que possam vir a impossibilitar o funcionamento da franquia.

É de suma relevância investigar se os procedimentos arbitrais estariam abrangidos na expressão pendências judiciais. Afinal, a omissão dos litígios que deveriam constar da circular de oferta de franquia pode ser o suficiente para que a parceria de franquia seja fulminada.

Para esta missão, constata-se que os métodos hermenêuticos são de grande valia e, ainda que não caiba esmiuçar neste trabalho a problemática da interpretação jurídica, cabe apontar quais deles são elencados pela doutrina especializada: (i) o gramatical $^{10}$ seria aquele que se alicerça no conteúdo e significado literal das palavras contidas no texto legal, consideradas em conjunto; (ii) o sistemático compara o texto "[...] com outros do mesmo repositório ou de Leis diversas, mas referentes ao mesmo objeto [...]" (MAXIMILIANO, 2002, p. 104); (iii) o histórico leva em consideração o contexto em que o dispositivo foi posto em vigor e eventualmente alterado, bem como seus antecedentes, de modo a extrair seu significado tanto a partir na legislação existente à época como das modificações implementadas em tal dispositivo; (iv) o

9 Em que estejam envolvidos o franqueador, as empresas controladoras e titulares de marcas, patentes e direitos autorais relativos à operação, e seus subfranqueadores.

10 Também denominado método literal. 
teleológico interpreta o objetivo da lei levando em conta a coerência e integração dos dispositivos que formam o ordenamento jurídico; e (v) o sociológico, interpreta a lei a partir do pressuposto de que ela é fruto de anseios sociais, considerando, desse modo, que sua compreensão perpassa a percepção do bem social que visa tutelar.

Lançar mão somente do método menos reflexivo - o literal levaria inequivocamente à conclusão de que a acepção de "pendência judicial" não englobaria os procedimentos arbitrais, já que esta expressão refere-se ao poder judiciário, ou seja, à jurisdição estatal. Contudo, todos os quatro outros métodos hermenêuticos convergem no sentido de que o conteúdo do inciso III do artigo $3^{\circ}$ da Lei de Franquia deve abranger também os procedimentos arbitrais, senão vejamos:

Pelos métodos sistemático e teleológico, verifica-se que o Código de Processo Civil estabelece em seu artigo $3^{\circ}, \S^{\circ}$, que a arbitragem constitui uma apreciação jurisdicional, tal qual ocorre nos processos judiciais. Ora, o propósito das demandas judiciais é o mesmo das arbitrais - solucionar conflitos. Desse modo, a informação sobre as "pendências", será da mesma relevância tanto para os litígios submetidos à jurisdição estatal como à arbitragem.

Com efeito, a própria Exposição de Motivos do Projeto da Lei de Franquia deixa clara que, ao obrigar a prévia apresentação da circular de oferta de franquia, este diploma legal tem por objetivo "não contrariar a essência do sistema de franquia, que é a parceria", mediante a conferência de "condições ao franqueado de conhecer, na íntegra, o negócio ao qual pretende aderir, assegurando-lhe o acesso a informações de forma a que possa decidir quanto à realização ou não do contrato de franquia".

Assim, sob a perspectiva do método teleológico, é inafastável a conclusão de que não seria coerente informar somente os litígios 
judiciais, omitindo-se os procedimentos arbitrais. E sob a do sistemático, ao equivaler a jurisdição estatal à arbitral, o Código de Processo Civil permeia a extensão do quanto exposto no dispositivo legal em tela, ampliando-a e fazendo-a incidir sobre a arbitragem.

Passando ao método histórico, releva salientar que a Lei de Franquia entrou em vigor pouco menos de dois anos antes da Lei da Arbitragem, o que poderia justificar a omissão dos procedimentos arbitrais, notadamente em vista "[...] da pouca ou nenhuma importância dada à arbitragem pela legislação anterior" (MAGALHÃES, 2012, p. $301)$.

Nota-se, desse modo, que o método hermenêutico histórico apresenta-se especialmente eficaz neste caso. Isto porque como assevera Maximiliano (2002, p. 114), propõe-se a analisar as disposições mais antigas de modo que não importe "[...] se não reproduzam as palavras: basta que fique a essência, o conteúdo, substancialmente se haja mantido o pensamento primitivo".

Finalmente, à luz do método sociológico, cumpre observar que o bem social tutelado pelo dispositivo legal da Lei de Franquia em comento é a conferência de certa segurança e previsibilidade do potencial franqueado quanto aos litígios relacionados à franquia.

Ocorre que caso um determinado franqueador adote a cláusula compromissória em todos os seus contratos de franquia, nenhum franqueado tomaria conhecimento dos litígios que questionem "[...] especificamente o sistema da franquia ou que possam diretamente vir a impossibilitar o funcionamento da franquia [...]"11, caso se interpretasse a disposição como limitada aos processos judiciais.

A adoção deste entendimento, além de ignorar por completo o 11 Artigo $3^{\circ}$, inciso III, da Lei de Franquia. 
bem social tutelado pelo dispositivo, viabilizaria ao franqueador lançar mão da cláusula compromissória como mecanismo para inibir o propósito do artigo $3^{\circ}$, inciso III, da Lei de Franquia, que, repita-se, é de permitir que o franqueado tome a decisão de estabelecer a relação de franquia ciente das pendências em que o franqueador esteja envolvido e que podem prejudica-la ${ }^{12}$.

Portanto, entender que os procedimentos arbitrais não estariam abrangidos corresponderia a permitir o esvaziamento do propósito informacional da circular de oferta de franquia. Isso somente seria viabilizado por uma interpretação literal que desconsiderasse os demais mecanismos de hermenêutica jurídica, e o resultado necessário seria uma acepção anacrônica e desvirtuada.

\subsection{A validade da cláusula compromissória perante o franqueado hipossuficiente}

No Brasil, via de regra o franqueador possui uma posição técnica e econômica mais favorecida que a do franqueado, sendo dele, na maioria das vezes, a iniciativa de firmar a cláusula compromissória. A realidade local demonstra que a franquia é mais atrativa ao empreendedor que $n a \tilde{o}$ possui substanciais recursos ou know how, e justamente por isso contrata a licença de uso da marca, fornecimento de tecnologia, prestação de serviços, etc. do franqueador.

Este empreendedor estará muito mais disposto à celebração da relação de franquia que aquele que dispõe de recursos para desenvolvimento de tecnologia e fixação da sua própria marca no

12 Cabe lembrar que o artigo $5^{\circ}$ da Lei de Introdução às Normas do Direito Brasileiro é expresso no sentido de que, na aplicação da lei, o juiz atenderá aos fins sociais a que ela se dirige e às exigências do bem comum. 
mercado, por exemplo. Ademais, tendo em vista que a relação de franquia usualmente visa viabilizar a difusão da marca e produtos do franqueador - e consequentemente dos seus produtos ou serviços -, conclui-se que este tenderá a ter maior representatividade no mercado em que atua.

Enfim, constata-se que os maiores franqueadores com atuação no Brasil constituem grupos econômicos com robusta capacidade financeira - muito maior que a do franqueado. Esta questão apresentase notadamente importante com relação ao franqueado que, exercendo a atividade de empresa mediante o contrato de franquia, tem nesta sua única fonte de renda - a realidade de um grande número de microempreendedores brasileiros.

Por esta razão, figura-se como especialmente relevante a análise da validade da validade da cláusula compromissória perante o franqueado hipossuficiente.

A questão da hipossuficiência pode ser analisada tanto no momento da celebração da cláusula arbitral no contrato de franquia como no momento em que o franqueado que teve seus direitos violados pretende instaurar um procedimento arbitral mas não dispõe de recursos para tanto.

Na primeira hipótese a problemática central é a liberdade de contratar. Atento aos problemas que poderiam surgir em decorrência da ampla liberdade conferida às partes celebrantes de um negócio jurídico, o legislador estatuiu, no artigo 421 do Código Civil, que a liberdade de contratar será exercida em razão e nos limites da função social do contrato.

À guisa das lições de Tepedino, Barboza e Moraes (2006, p. 9), cabe apontar que a observância à função social na celebração do contrato redunda em sua vinculação não somente à vontade das partes, 
mas também aos valores sociais estabelecidos pelo ordenamento pátrio. Afinal, a manifestação volitiva das partes não poderia sobrepor-se aos interesses socialmente relevantes.

Desse modo, apesar de não ser possível estabelecer um conceito fechado do que seria a função social do contrato, é possível identificá-la nos casos concretos. Mas é certo que não estaria sendo observada caso um dos contratantes incorresse em quebra da boa-fé objetiva ${ }^{13}$ ou e em abuso de direito ${ }^{14}$ quando da celebração da cláusula compromissória.

No caso em tela, por exemplo, ela restará inobservada caso a convenção arbitral seja estabelecida em razão de conduta abusiva de um franqueador que conhece a situação do franqueado que não teria condições de instaurar uma arbitragem, mas ainda assim o compele a firma-la.

Caso o objetivo da celebração da cláusula compromissória seja o de aproveitar-se da hipossuficiência do franqueado, restará flagrante a extrapolação da função social da convenção arbitral e sua consequente invalidade. Não caberia permitir ao franqueador travestir na arbitragem uma verdadeira barreira ao acesso à justiça pelo franqueado.

A propósito, a garantia do acesso à justiça é a questão central no que se refere à hipossuficiência constatada no momento da instauração do procedimento arbitral. Muito embora mesmo a persecução de direitos mediante a submissão de pretensões à jurisdição estatal não exonere a parte de custos significativos - relacionados principalmente às custas judiciais e honorários advocatícios e periciais -, estes custos serão

$13 \mathrm{O}$ instituto da boa-fé objetiva encontra-se positivado no artigo 422 do Código Civil, de acordo com o qual os contratantes são obrigados a guardar, assim na conclusão do contrato, como em sua execução, os princípios de probidade e boa-fé.

14 A ilicitude do abuso de direito está estabelecida no artigo 187 do Código Civil, de acordo com o qual comete ato ilícito o titular de um direito que, ao exercê-lo, excede manifestamente os limites impostos pelo seu fim econômico ou social, pela boa-fé ou pelos bons costumes. 
substancialmente menores se comparados à arbitragem.

Frise-se, no que se refere aos processos judiciais, o artigo 98 do Código de Processo Civil estabelece que a pessoa natural ou jurídica, brasileira ou estrangeira, com insuficiência de recursos para pagar as custas, as despesas processuais e os honorários advocatícios relacionados tem direito à gratuidade da justiça.

Fica claro que a lei ocupa-se de repelir o cerceamento do acesso à justiça à parte hipossuficiente ${ }^{15}$. A esse respeito, cabe trazer à baila as lições que chamam atenção ao fato de que o acesso à justiça não deve ser adotado sob uma abordagem estritamente formal, uma vez que uma das suas finalidades preponderantes é a de "[...] produzir resultados que sejam individual e socialmente justos" (CAPPELLETTI; GARTH, 1988, p. 8).

Impor ao franqueado que suporte os custos da instauração de um procedimento arbitral pode muito bem significar para este franqueado uma limitação à sua garantia de acesso à justiça, notadamente nos casos em que se figure flagrante a violação aos seus direitos por parte do franqueador.

Portanto, em que pese relevante doutrina defender a inafastabilidade da eficácia da cláusula arbitral, esta não pode ser entendida como absoluta. Mesmo diante das relevantes vantagens trazidas pela arbitragem, não poderá ser negada ao franqueado em posição de hipossuficiência em relação ao franqueador a possibilidade de submeter à jurisdição estatal sua pretensão de inaplicabilidade da arbitragem.

Com efeito, tendo a legislação se ocupado em permitir à parte hipossuficiente exonerar-se de pagamentos devidos no curso de um

15 Note-se que também o Projeto de Lei n. 7.108/2014, que propõe alterações à Lei de Arbitragem, consubstancia uma preocupação com relação aos custos relacionados ao procedimento arbitral. De acordo com seu texto, a arbitragem poderia ser adotada em litígios envolvendo relações trabalhistas, mas ressalva que somente a funcionários em posições hierárquicas mais relevantes - e, portanto, com melhores condições financeiras - poderiam pactuar a cláusula compromissória. 
processo judicial, não seria lógico, tampouco razoável, entender que, em relação aos custos relacionados à arbitragem - substancialmente mais elevados -, não houvesse qualquer proteção à parte economicamente vulnerável.

De todo modo, é importante deixar claro que esta será uma situação excepcional, uma vez que a convenção arbitral não representa a priori, violação à garantia contida no artigo $5^{\circ}$, inciso $\mathrm{XXXV}$ da Constituição Federal ${ }^{16}$. Neste esteio, é certo que recairá sobre o franqueado hipossuficiente que acordou a cláusula compromissória o ônus de comprovar as barreiras que esta representaria, no caso concreto, à efetividade do seu acesso à justiça.

\subsection{Os requisitos para a inserção da cláusula compromissória nos contratos de franquia}

A vinculação das partes ao juízo arbitral depende da observância de dois pressupostos principais, quais sejam, a capacidade civil dos contratantes e o objeto do litígio, que haverá de ser necessariamente um bem disponível, como bem apontam Ribeiro e Almeida (2011, p. 166).

Além disso, a Lei da Arbitragem estabelece diversas solenidades para a celebração da convenção arbitral. Isto porque um dos seus notórios propósitos é que as partes envolvidas em um conflito, ao se furtarem à prerrogativa de submeterem suas pretensões à tutela estatal - que seria mais formal com vistas a assegurar-lhes de modo mais robusto suas garantias $^{17}$ - manifestem sua anuência neste sentido de modo expresso e inequívoco.

16 A lei não excluirá da apreciação do Poder Judiciário lesão ou ameaça a direito.

17 O que não significa, por óbvio, que na arbitragem estas garantias não sejam asseguradas, mas tão somente que os procedimentos sejam simplificados conforme seja a complexidade do litígio. 
Assim, é possível traçar os seguintes requisitos aplicáveis à inserção da cláusula compromissória no contrato de franquia: (i) os bens objeto da demanda submetida à arbitragem devem ser disponíveis ${ }^{18}$; (ii) devem os contratantes possuir capacidade civil; e (iii) as solenidades estabelecidas na Lei de Arbitragem para a celebração desta convenção de arbitragem ${ }^{19}$ deverão ser estritamente observadas.

Direitos patrimoniais disponíveis são aqueles que tenham valor econômico e possam ser livremente transacionados ou onerados por seus titulares. A norma do artigo $1^{\circ}$ da Lei de Arbitragem, segundo a qual somente eles poderão ser objeto de demanda arbitral, encontrase encampada pelo artigo 852 do Código Civil, nos termos do qual é expressamente vedado convencionar a arbitragem para solução de questões de estado, de direito pessoal de família e de outras que não tenham caráter estritamente patrimonial.

É da própria natureza do contrato de franquia que os bens objeto dele sejam de natureza disponível, uma vez que constituem notadamente a propriedade intelectual das partes e os insumos necessários para o exercício da atividade empresarial correspondente. Portanto, via de regra este requisito não será um óbice à adoção da arbitragem na relação de franquia.

No que se refere ao segundo requisito, apenas estarão aptas a valer-se da arbitragem pessoas dotadas de capacidade civil nos termos do artigo $1^{\mathrm{o}}$ e seguintes do Código Civil ${ }^{20}$, ou ainda, a administração

18 Artigo $1^{\circ}$ da Lei da Arbitragem.

19 A convenção de arbitragem é entendida tanto como a cláusula compromissória como o compromisso arbitral. De todo modo, considerando que o presente trabalho limita-se às questões da arbitragem no âmbito dos contratos de franquia, limitaremos a abordagem à cláusula compromissória, uma vez que diz respeito ao compromisso de arbitragem relativo ao contrato em que é inserida.

20 Art. $1^{\circ}$. Toda pessoa é capaz de direitos e deveres na ordem civil. Art. $2^{\circ}$. A personalidade civil da pessoa começa do nascimento com vida; mas a lei põe a salvo, desde a concepção, os direitos do nascituro. Art. $3^{\circ}$. São absolutamente incapazes de exercer pessoalmente os atos da vida civil os menores de 16 (dezesseis) anos. Art. $4^{\circ}$. São incapazes, relativamente a certos atos ou à maneira de os exercer: I - os maiores de 
pública direta e indireta (artigo $1^{\circ}, \S 1^{\circ}$, da Lei da Arbitragem), desde que devidamente representada.

As pessoas capazes poderão, sem óbices, serem representadas na celebração da cláusula arbitral assessória ao contrato de franquia, assim como os relativamente incapazes devidamente assistidos poderão firmar tal pacto. Mas no que se refere aos absolutamente incapazes, a doutrina não possui entendimento uníssono.

Como seus bens não podem ser livremente transacionados ou onerados, parte dos autores especializados entende que a celebração da convenção arbitral por seus representantes legais violaria o primeiro requisito acima mencionado (os bens objeto do litígio devem ser disponíveis).

Mas este entendimento não prevalece pela simples razão de que, caso os representantes legais estejam atuando dentro dos limites que lhe incumbem e o objeto da demanda diga respeito a bens que poderiam ser alienados ou onerados dentro destes mesmos limites, nada obstaria que celebrassem a convenção arbitral em nome dos seus representados.

Esta mesma linha de raciocínio aplica-se, por exemplo, às massas falidas, espólios e condomínios: casos os representantes tenham sido devidamente autorizados a celebrarem o compromisso arbitral por quem tem poderes para tanto e o façam dentro dos limites estabelecidos, restará atendido o requisito da capacidade civil.

Passando ao requisito da observância das solenidades específicas para a celebração da cláusula arbitral no contrato de franquia, devem ser observados primordialmente os requisitos do artigo $4^{\circ}$ da Lei da Arbitragem, cujo $\S 1^{\circ}$ estabelece que esta deve ser estipulada por escrito, 
podendo estar inserta no próprio contrato ou em documento apartado que a ele se refira. Já o $\S 2^{\circ}$ deste mesmo dispositivo trata da inserção da cláusula compromissória nos contratos de adesão.

De acordo com seus termos, a cláusula compromissória somente terá eficácia nos contratos de adesão se o aderente tomar a iniciativa de inseri-la arbitragem ou concordar, expressamente, com a sua inserção por escrito em documento anexo ou em negrito, com a assinatura ou visto especialmente para essa cláusula.

Esta solenidade ganha especial relevo em vista da realidade pátria das relações de franquia. Na prática, observa-se que a maioria das franquias existentes firmam-se por meio de contratos de adesão cujas cláusulas são unilateralmente estabelecidas pelos franqueadores - via de regra, agentes econômicos com forte presença nos setores em que atuam.

Contudo, esta realidade não basta para que se estatua que todo contrato de franquia é de adesão. Isto porque o estabelecimento prévio de cláusulas pelo franqueador é uma prática difundida, mas não um mandamento legal. $O$ fato de a realidade não se alinhar à liberdade que as partes têm de estabelecer as cláusulas do contrato de franquia não bastaria para a conclusão de que este seria sempre de adesão.

Portanto, em se verificando no caso concreto que o contrato de franquia figura-se como sendo de adesão, a cláusula compromissória somente será válida caso sua inserção tenha sido decorrente de iniciativa do franqueado ou, caso contrário, conste o referido pacto arbitral por escrito em documento anexo, ou ainda, em negrito no próprio contrato de franquia, com a assinatura ou visto específico. 


\section{CONCLUSÃO}

Os contratos de franquia vêm ganhando enorme relevância; classificados como contratos de colaboração, sua dogmática despontou nos últimos anos como essencial ao interesse geral das relações empresariais e do desenvolvimento da economia.

Esta espécie de colaboração para o exercício da empresa é recente se comparada àquela estabelecida por meio de sociedades empresárias, e justamente por esta razão não encontra um arcabouço jurídico-normativo tão robusto como o aplicável a estas últimas.

A partir do quanto exposto neste trabalho, é possível verificar, de toda sorte, que as soluções para questões atinentes à arbitragem no contrato de franquia encontram-se encampadas de modo claro no nosso ordenamento jurídico, ainda que para sua identificação seja necessário lançar mão da hermenêutica.

Foi possível identificar que dentre estas questões, as principais são, de um lado, a obrigação de o franqueador informar ao franqueado, no âmbito da circular de oferta de franquia, os procedimentos arbitrais relativos à franchising em que esteja envolvido, da mesma forma como deve fazê-lo com relação às pendências judiciais, e de outro, a possibilidade de um franqueado em posição de hipossuficiência relativamente ao franqueador pleitear a inaplicabilidade da cláusula compromissória.

Constatou-se que, primeiramente, apesar do artigo $3^{\circ}$, inciso III, da Lei de Franquia não mencionar expressamente os procedimentos arbitrais, o fim perseguido pela norma é clara e inequivocamente no sentido de que também estes devem ser informados. A omissão dos 
procedimentos arbitrais no mencionado dispositivo de modo algum decorre da intenção da lei de dispensar o franqueador esclarecer ao franqueado os procedimentos arbitrais em que esteja envolvido, mas sim do fato de que a Lei de Franquia precede a Lei da Arbitragem.

Quanto ao franqueado hipossuficiente, é possível que se pleiteie a invalidade da cláusula compromissória sempre que restar claro que esta não atende à sua função social - o que se verificará, inclusive, nas hipóteses de abuso de direito e violação à boa fé objetiva -, bem como representar uma barreira à tutela da garantia do acesso à justiça.

Uma vez observadas as formalidades cabíveis, ainda que a instituição da cláusula não represente, a priori, violação à garantia de acesso à justiça, deve ser concedido ao franqueado hipossuficiente a possibilidade de demonstrar que as barreiras à arbitragem, notadamente relacionadas aos custos, não configuraria tal violação. Esta verificação não deve ser feita a partir de uma abordagem estritamente formal, mas sim investigando os resultados que emergiriam da impossibilidade de apresentar suas pretensões senão pela arbitragem.

Finalmente, por força do artigo $4^{\circ}$ da Lei de Arbitragem, a convenção arbitral somente poderá ser estabelecida na relação de franquia caso se dê de maneira expressa no próprio contrato ou em documento apartado que a ele se refira. Os contratos de franquia caraterizados como de adesão somente poderão conter cláusula compromissória por iniciativa do franqueado ou, caso contrário, constando em documento anexo, ou ainda, em negrito no próprio contrato de franquia, com a assinatura ou visto específico

\section{REFERÊNCIAS}

SCIENTIA IURIS, Londrina, v.21, n.1, p.125-154, Mar.2017 DOI: 110.5433/2178-8189.2017v21n1p125 
BRAGA, Carlos D. A. Contrato de franquia empresarial. In: COELHO, Fábio Ulhoa (Coord.) Tratado de Direito Comercial. v. 6. São Paulo: Saraiva, 2015. p. 168-198.

BRASIL. Constituição da República Federativa do Brasil de 1988. Disponível em $<$ http://www.planalto.gov.br/ccivil_03/constituicao/ ConstituicaoCompilado.htm>. Acesso em: 4 dez. 2016.

. Decreto-lei $\mathrm{n}^{\circ} 2.848$, de 07 de dezembro de 1940. Código Penal. Disponível em $<$ http://www.planalto.gov.br/ccivil_03/decretolei/Del2848compilado.htm>. Acesso em 4 dez. 2016.

. Exposição de Motivos do Projeto da Lei n. 8.955, de 15 de dezembro de 1994. Dispõe sobre o contrato de franquia empresarial (franchising) e dá outras providências. Disponível em $<$ http://www2. camara.leg.br/legin/fed/lei/1994/lei-8955-15-dezembro-1994-349836exposicaodemotivos-149737-pl.html>. Acesso em: 4 dez. 2016.

. Lei n. 8.955, de 15 de dezembro de 1991. Dispõe sobre o contrato de franquia empresarial (franchising) e dá outras providências. Diário do Congresso Nacional, Brasília, DF, 9 abr. 1991. Disponível em < http://www2.camara.leg.br/legin/fed/lei/1994/ lei-8955-15-dezembro-1994-349836-exposicaodemotivos-149737-pl. html >. Acesso em: 4 dez. 2016.

. Lei n. 9.307, de 23 de setembro de 1996. Dispõe sobre a arbitragem. Diário do Congresso Nacional, Brasília, DF, 23 set. 1996. Disponível em <http://www.planalto.gov.br/ccivil_03/leis/ L9307.htm>. Acesso em: 4 dez. 2016.

. Lei n. 10.406, de 10 de janeiro de 2002. Institui o Código Civil. Diário do Congresso Nacional, Brasília, DF, 10 jan. 2002. Disponível em < http://www.planalto.gov.br/ccivil_03/leis/2002/ 110406.htm>. Acesso em 4 dez. 2016. 
. Lei n. 13.105, de 16 de março de 2015. Código de Processo Civil. Diário do Congresso Nacional, Brasília, DF, 16 mar. 2015. Disponível em <https://www.planalto.gov.br/ccivil_03/_ ato2015-2018/2015/lei/113105.htm>. Acesso em: 4 dez. 2016.

CACHAPUZ, Rozane da Rosa; CONDADO, Elaine C. Gomes. Arbitragem: instrumento efetivo de acesso à justiça. Scientia Iuris, Londrina, v. 12, p. 95-116, 2008.

CAPPELLETTI, Mauro e GARTH, Bryant. Acesso à justiça. Porto Alegre: Sérgio Antonio Fabris Editor, 1988.

CINTRA, Antonio Carlos de Araújo; GRINOVER, Ada Pellegrini; DINAMARCO, Cândido Rangel. Teoria geral do processo. 25. ed. rev. e atual. São Paulo: Editora Malheiros, 2009.

COELHO, Fábio Ulhoa. Curso de direito comercial. v. 3. $17^{\mathrm{a}}$ ed. rev., atual. e ampl. São Paulo: Revista dos Tribunais, 2016.

. Manual de direito comercial. 26. ed. São Paulo: Saraiva,

2014.

FORGIONI, Paula Andrea. A evolução do direito comercial brasileiro: da mercancia ao mercado. 2. ed. rev., atual. e ampl. São Paulo: Revista dos Tribunais, 2012.

MAGALHÃES, Tiago Fantini. Reflexões acerca da cláusula compromissória: análise de situações concretas. In: BOTREL, Sérgio (Coord.) Direito societário: análise crítica. São Paulo: Saraiva, 2012. p. 289-307.

MASSALI, Wilson Euclides Guazzi; CACHAPUZ, Rozane da Rosa. Arbitragem: uma saída liberal à crise do judiciário. Scientia Iuris, 
Londrina, v. 15, n. 2, p. 165-183, dez. 2011.

MAXIMILIANO, Carlos. Hermenêutica e aplicação do direito. 19. ed. Rio de Janeiro: Forense, 2002.

RIBEIRO, Marcia Carla Pereira; ALMEIDA, Caroline Sampaio de. A importância da cláusula compromissória nos contratos empresariais como fortalecimento das relações negociais. Revista de Arbitragem e Mediação, São Paulo, v. 28, p. 161-182. jan./mar. 2011.

TEPEDINO, Gustavo; BARBOZA, Heloisa Helena; MORAES, Marina Celina Bodin de. Código civil interpretado conforme a Constituição da República. Rio de Janeiro: Renovar, 2006. v. 2.

Como citar: BIANA, Higor da Silva; SANT'ANNA, Leonardo da Silva. Apontamentos sobre a arbitragem no contrato de franquia. Scientia Iuris, Londrina, v. 21, n. 1, p.125-154, mar. 2017. DOI: 10.5433/2178-8189.2017v21n1p125. ISSN: 2178-8189.

Recebido em: 04/05/2016

Aprovado em: 20/12/2016 